\title{
THE BLACK STEM RUST AND THE BARBERRY
}

BY

E. C. STAKMAN

Pathologist in Charge of Barberry Eradicåtion Campaign, Office of Cereal Investigations, Bureau of Plant Industry

\section{CONTENTS}

Damage Done by Black Stem Rust . . . . . . . . .

How to Tell Black Stem Rust . . . . . . . . . . . . 5

Grains and Grasses Attacked by Black Stem Rust . . . . . . 6

The Cause of Rust . . . . . . . . . . . . . . 6

Life Story of the Rust Parasite . . . . . . . . . 8

How Does Rust Live over Winter? . . . . . . . . . . 10

Conditions Which Favor Rust Development . . . . . . . . 12

How to Reduce Rust Losses by Cultural Methods . . . . . . 12

Eradication of the Common Barberry to Reduce Rust Losses . . 16

Harmful and Harmless Barberries . . . . . . . . . . 17

List of Barberries and Related Plants . . . . . . . 19

Distribution of the Barberry . . . . . . . . . . . . . 20

The Common Barberry Running Wild . . . . . . . . 20

Native Barberries . . . . . . . . . . . . . . . 21

How Severely do Barberries Rust? . . . . . . . . . . . 21

The Spread of Rust from the Barberry . . . . . . . . . 22

Importance of the Barberry in Spreading Rust . . . . . . 25

Barberry Laws . . . . . . . . . . . . . 26

Denmark Controls Rust . . . . . . . . . . . . 28

Dig Up the Common Barberry . . . . . . . . . 28

Separate from Yearbook of the

Department of Agriculture, 1918

No. 796 



\section{THE BLACK STEM RUST AND THE BARBERRY.}

By E. C. Stakman,

Pathologist in Charge of the Barberry Eradication Campaign, Office of Cereal Investigations, Burcau of Plant Industry.

THE BLACK STEM RUST of wheat, oats, barley, rye, 1 and about 50 cultivated and wild grasses is one of the most destructive diseases of these plants. There are several distinct kinds of rust, but the black stem rust causes greater total losses than any of the others, although in some sections one or more of the other rusts may be more important. This paper deals only with the black stem rust (Puccinia graminis).

\section{DAMAGE DONE BY BLACK STEM RUST.}

The black stem rust is found practically wherever grain is grown in the United States. It is also found generally in Canada, South America, Europe, Asia, Africa, and Australia. In many sections of the United States black stem rust is the limiting factor in grain production. While it is especially destructive to wheat, it does a great deal of damage also to oats, barley, and rye. It is most serious on spring wheat, but sometimes it also may cause enormous losses of winter wheat. In the Gulf States it is sometimes so serious as to make it entirely unprofitable to grow wheat and other small grains.

At irregular intervals rust develops ravaging epidemics which sweep across great areas of the grain-growing regions and almost completely destroy immense quantities of grain. Some rust epidemics have been so serious and widespread as to cause a decided shortage of foodstuffs. It is necessary only to recall the terrible epidemics of 1904 and 1916. It was estimated that in 1904 the rust caused a loss of $\$ 20,000,000$ in Minnesota and the two Dakotas. In 1916 the production of wheat in Minnesota, North Dakota, South Dakota, and Montana was reduced by over 200,000,000 bushels from that of the previous year. This appalling loss was caused very largely by the black stem rust. After making 
due allowance for the reduction in acreage in some of these States and after making allowance for somewhat unfavorable weather, the fact remains that the principal cause of this enormous loss was the black stem rust. Thousands of acres of wheat never were cut. The grain would not have paid for harvesting and thrashing. Hundreds of farmers in the spring-wheat region were practically ruined on account of the almost complete failure of the wheat crop. In addition to the enormous reduction in yield, the quality of the wheat produced was very inferior. Much of it weighed only 40 to 50 pounds to the bushel. (See Pls. I and II.)

In 1916 the average yield of spring wheat in North Dakota was only $5 \frac{1}{2}$ bushels per acre, compared with an average yield of more than 18 bushels in 1915 and a 10-year average of more than 11 bushels an acre. In South Dakota the average yield in 1916 was not quite 7 bushels per acre, as compared with 17 bushels in 1915 and a 10 -year average of $10 \frac{1}{2}$ bushels. The greatest reduction in total production occurred in North Dakota. The production in that State in 1915 was about $150,000,000$ bushels, while in the severe rust year of 1916 it was less than 40,000,000 bushels. The production in Minnesota in 1915 was about $70,000,000$ bushels, but it dropped to $28,000,000$ bushels in 1916 . The most conservative estimate places the loss of wheat in the United States due to the black stem rust in 1916 at 180,000,000 bushels, while the loss in Canada was estimated at about $100,000,000$ bushels. In Canada and the United States, therefore, the black stem rust detroyed at least $280,000,000$ bushels of wheat in a single year. To this must be added the loss of oats, barley, and rye. Reports showed very clearly that the loss of barley and oats in some localities often amounted to as much as 15 to 25 per cent of the crop.

Any plant disease which causes such enormous losses certainly deserves careful study. Whatever measures are known for reducing rust losses should be applied immediately. Not only farmers, grain dealers, and millers are interested in the grain crop, but every one in the country is interested, either directly or indirectly.

In order to apply control measures, it is necessary to know something about the nature of the disease. A brief life story of the parasite causing the black stem rust therefore is given. 


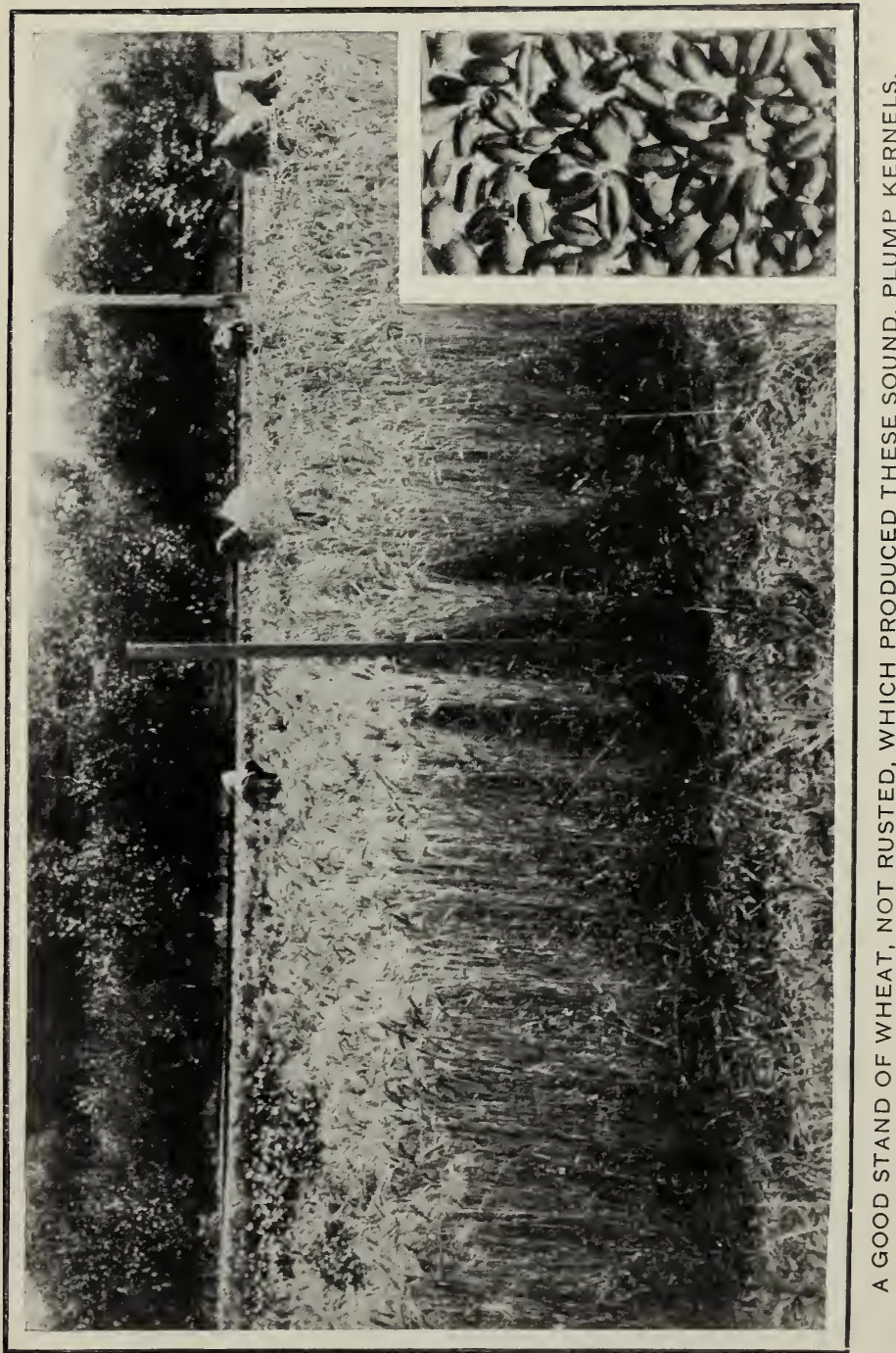




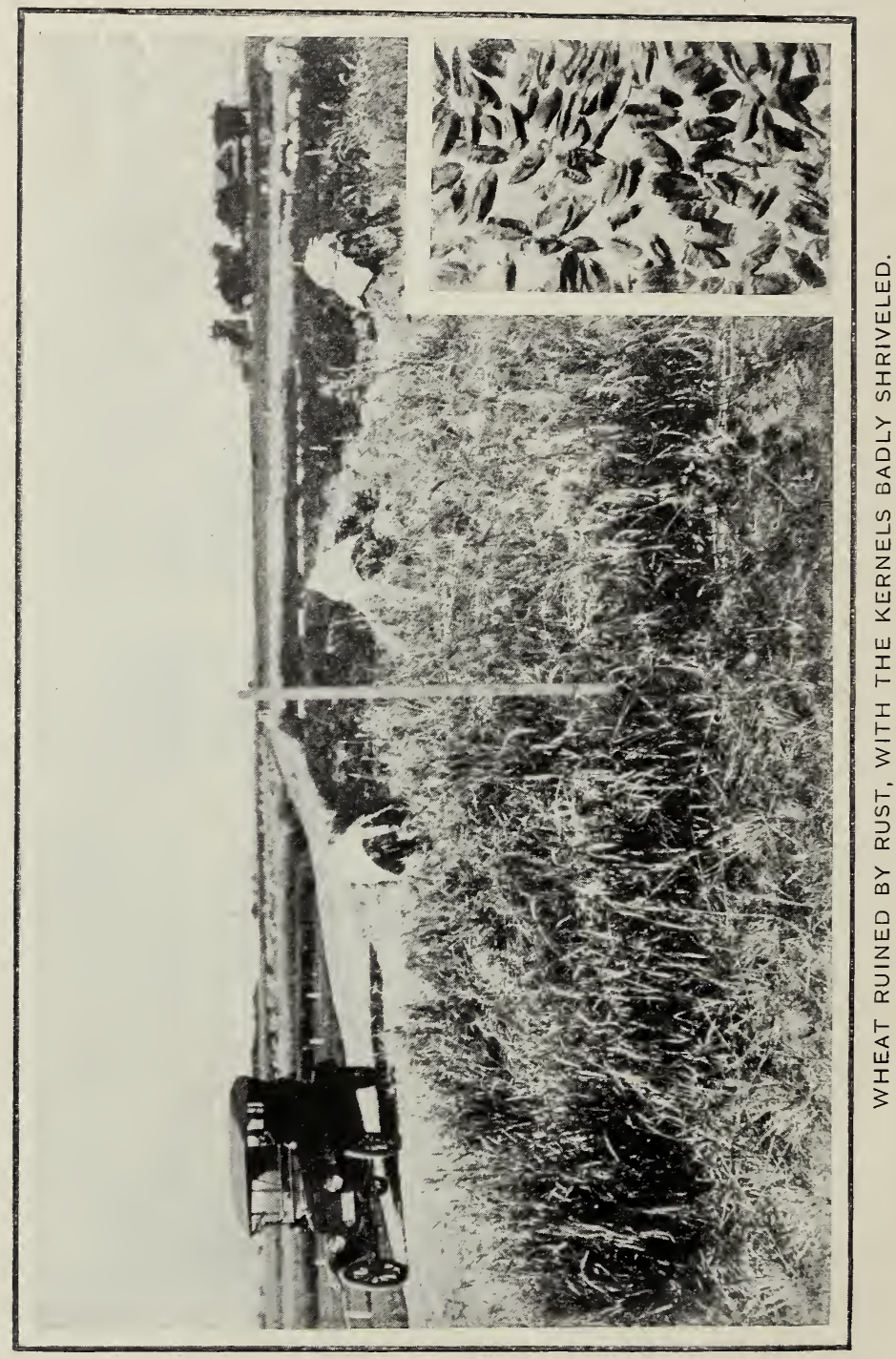




\section{THE LIBRARY}

OF THE

UNIVERSIIY OF ILLINOIS 

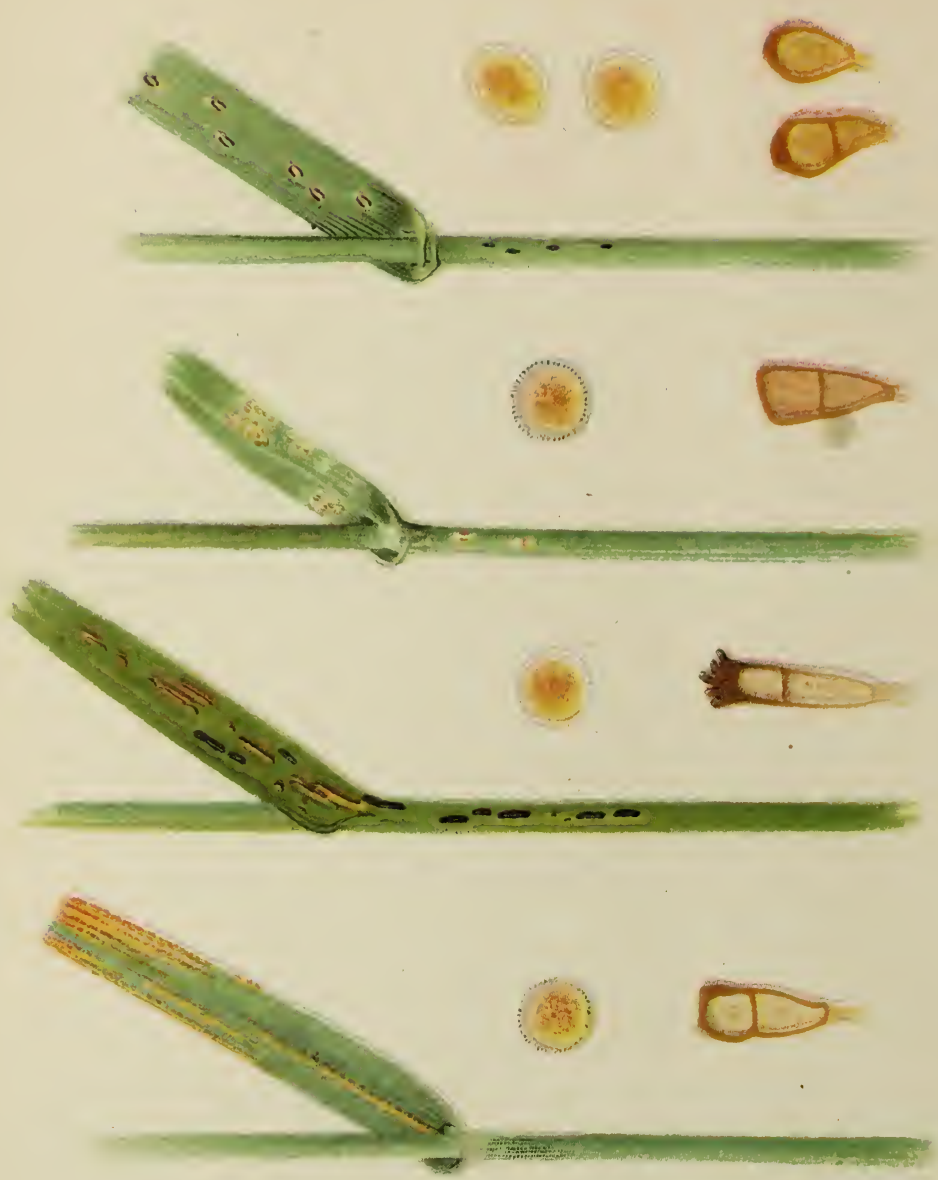

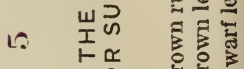
zo. ठํำ

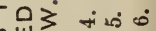

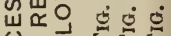

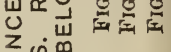
iu

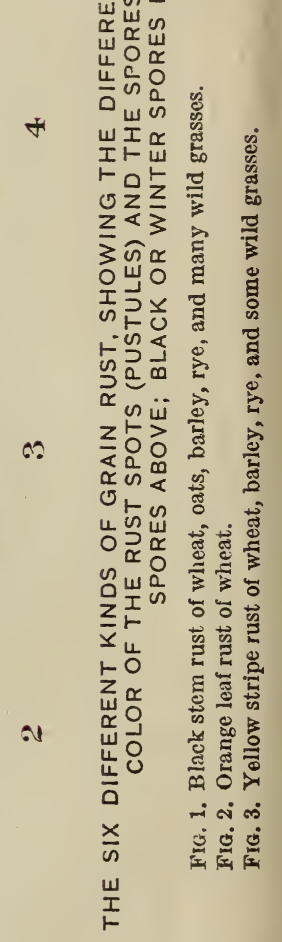

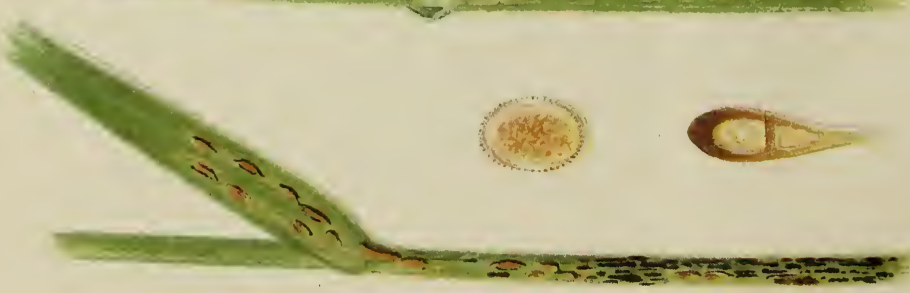




\section{HOW TO TELL BLACK STEM RUST.}

Black stem rust is often confused with other rusts of grain which are similar in appearance but act differently. The common rusts are the black stem rust, the yellow stripe rust, the orange leaf rust of wheat, the crown rust of oats, the brown leaf rust of rye, and the dwarf leaf rust of barley. Each of these rusts has a red or summer stage and a black or winter stage. They can be distinguished from each other by the shape and color of the rust spots (pustules) and by their position on the plant. Plate III shows the different kinds of rust.

The black stem rust (Puocinia graminis) occurs on wheat, oats, barley, rye, and many grasses throughout the United States. (See Pl. III, fig. 1.) It also develops on the common barberry. It is the only one of the grain rusts which develops on this shrub. The yellow stripe rust (Puccinia glumarum) occurs on wheat, barley, rye, and several wild grasses. (See Pl. III, fig. 2.) It seems to be confined to the West and is especially common west of the Rocky Mountains, where it sometimes becomes quite destructive. The orange leaf rust (Puccinia triticina) is found on wheat and possibly also on several grasses. (See Pl. III, fig. 3.) It occurs practically wherever wheat is grown in the United States and is capable of doing much damage, especially in the Southern States. Crown rust of oats (Puccinia coronifera) attacks oats and several grasses. (See Pl. III, fig. 4.) It is often serious on oats in certain sections of the country. The brown rust of rye (Puccinia dispersa) attacks rye and possibly a few grasses (see Pl. III, fig. 5), while the dwarf leaf rust of barley (Puccinia simplex) seems to be confined almost entirely to barley and seldom does much damage, except possibly in California. (See Pl. III, fig. 6.)

Each kind of grain may be attacked by several distinct rusts. For instance, wheat may be attacked by the black stem rust, the yellow stripe rust, and the orange leaf rust. These rusts are different and should not be confused with each other. Barley can be attacked by the black stem rust, the yellow stripe rust, and the dwarf leaf rust; rye by the black stem rust, the yellow stripe rust, and the brown leaf rust; and oats by the black stem rust and the crown.rust. 
These rusts differ from each other so much that what is said about one does not necessarily apply to the others.

\section{GRAINS AND GRASSES ATTACKED BY BLACK STEM RUST.}

Wheat, oats, barley, rye, spelt, emmer, einkorn, timothy, redtop (Agrostis alba), orchard grass (Dactylis glomerata), and various other forage grasses are attacked by the black stem rust. In addition to the cereals and cultivated grasses many wild grasses also are subject to rust. Among the most important of these grasses are wild barley or squirrel-tail grass (Hordeum jubatum), quack-grass (Agropyron repens), slender wheat-grass (Agropyron smithii), awned wheatgrass (Agropyron caninum), bottle brush-grass (Hystrix patula), practically all of the wild rye-grasses (Elymus spp.), fescue grasses (Festuca spp.), koeleria (Koeleria cristata), sweet vernal grass (Anthoxanthum puelli), and several brome-grasses (Bromus spp.). (See Pl. IX, fig. 2.)

Although all of these plants can be attacked by the black stem rust, there are forms or races of this rust which act somewhat differently. For instance, there is one race of black stem rust on wheat and barley. This race does not attack oats or rye normally. There is also a race on rye and barley which does not attack wheat and oats. Again, the race on oats attacks only oats and certain grasses. The race on timothy attacks only timothy and several wild grasses. All of the races can attack several of the wild grasses, but not all of them can attack the same grasses. This explains apparently conflicting observations. For instance, it is quite possible that a field of oats might be badly rusted while a near-by wheat field might be almost entirely free. In the same way, a wheat field might be badly rusted and a neighboring field of rye might be practically free from rust, because the forms of rust on these different crops are different.

\section{THE CAUSE OF RUST.}

Black stem rust is caused by a parasitic fungous plant. Animal parasites are better known to most people than plant parasites. Everyone knows that tiny animals, such as lice, ticks, fleas, mites, and maggots, live as parasites on horses, cattle, sheep, swine, chickens, and other animals. These mi- 
nute animal parasites cause such diseases as itch, scab, mange, staggers, and warbles.

In the same way there are uncounted numbers of tiny plants which live as parasites on or in larger plants. There is scarcely a plant of the garden or field, of the prairie or woodland, which is not subject to attack by one or more of these plant parasites. Plant parasites do not make their own food, as most plants do, but they grow on or in other plants and steal their food. . The plant which is being robbed is called the host plant, although its parasitic visitor is destructive to it. Plant parasites are mostly fungi or bacteria and cause such plant diseases as rusts, smuts, mildews, leaf spots, fruit molds, rots, and wilts.

The black stem rust is caused by one of these tiny plant parasites, which is known as Puccinia graminis. The fungus which causes black stem rust is a small colorless moldlike plant. The other rusts shown in Plate III are caused by closely related fungous parasites, which differ from each other just as different kinds of roses or apples or wheat differ from each other.

The parasitic plant wnich causes black stem rust is so small that it can be seen only with a microscope. It differs from the larger plants which we know in not having definite roots, stems, and leaves. The rust parasite consists of numerous minute colorless threads or tubes, which grow, branch, and twist among the tissues of grain and grass plants. The threads send little suckers into the cells of the host plant and thus get their food by absorbing its juices. The growth of the rust parasite continues until a dense network of threads is formed, and then seed is produced in the host plant. The seeds of the parasite are known as spores. Immense numbers of spores are formed. They are extremely small, but they produce rust plants just as the seeds of wheat produce wheat plants.

The rusts get their name because they produce yellowish, reddish, or brownish spores which may be so numerous that they make the plants look as if they were covered with the well-known iron rust. The black stem rust gets its name because the long spots (pustules) of black spores on the stems of grain plants are so conspicuous. (See Pl. III, fig. 1.) 
The weather, therefore, does not cause plant rusts, al. though there is a popular belief that it does. But the rapidity with which the parasitic plant causing rust grows and spreads depends on favorable weather, just as the growth of wheat and corn depends on favorable weather.

\section{LIFE STORY OF THE RUST PARASITE.}

There are several stages of black stem rust-the clustercup or early-spring stage, the red or summer stage, and the black or winter stage. (See Pl. IV.) The difference in the appearance of the rust at different times is due to the formation of different kinds of spores.

The rust starts on the barberry in the spring. Yellowish or orange-colored rust spots are formed on the leaves (Pl. IV, fig. 1), young twigs, and berries. The spots on the under side of the leaves (Pl. IV, fig. 2) consist of many small cups (cluster cups) which contain thousands of cluster-cup or spring spores (Pl. IV, fig. 3). These spores (Pl. IV, fig. 4) can not infect other barberry plants, but they are blown about by the wind and may fall on grain or grass plants and cause infection (Pl. IV, figs. 5 and 6 ). The red-spore or summer stage is the result.

The reddish brown rust pustules (Pl. IV, fig. 7) on grain and grasses consist of great numbers of minute, reddish or golden-colored spores (Pl. IV, fig. 8). These spores are so small and light that they are easily blown long distances by the wind. They may fall on grain or grass plants and germinate (Pl. IV, fig. 9) in the moisture formed by rain or dew on the surfaces of the plants. They often germinate within 4 or 5 hours, sending out long, slender, threadlike tubes which grow across the surface of the plant until they reach a breathing pore (Pl. IV, fig. 10). They then grow through this pore and branch in the tissues of the plant until a dense network of threads is formed. They then produce another crop of red spores (Pl. IV, fig. 11) which break through the skin (epidermis) of the plant, are exposed to the air, and are in turn blown about by the wind. They may fall on the grain or grass plants, germinate, and send their tubes into the plants, and these tubes may branch and produce more red rust pustules. Thus, new plants are continually infected and successive crops of red spores are pro- 
Yearbook U. S. Dept. of Agriculture, 191

PLATE IV.

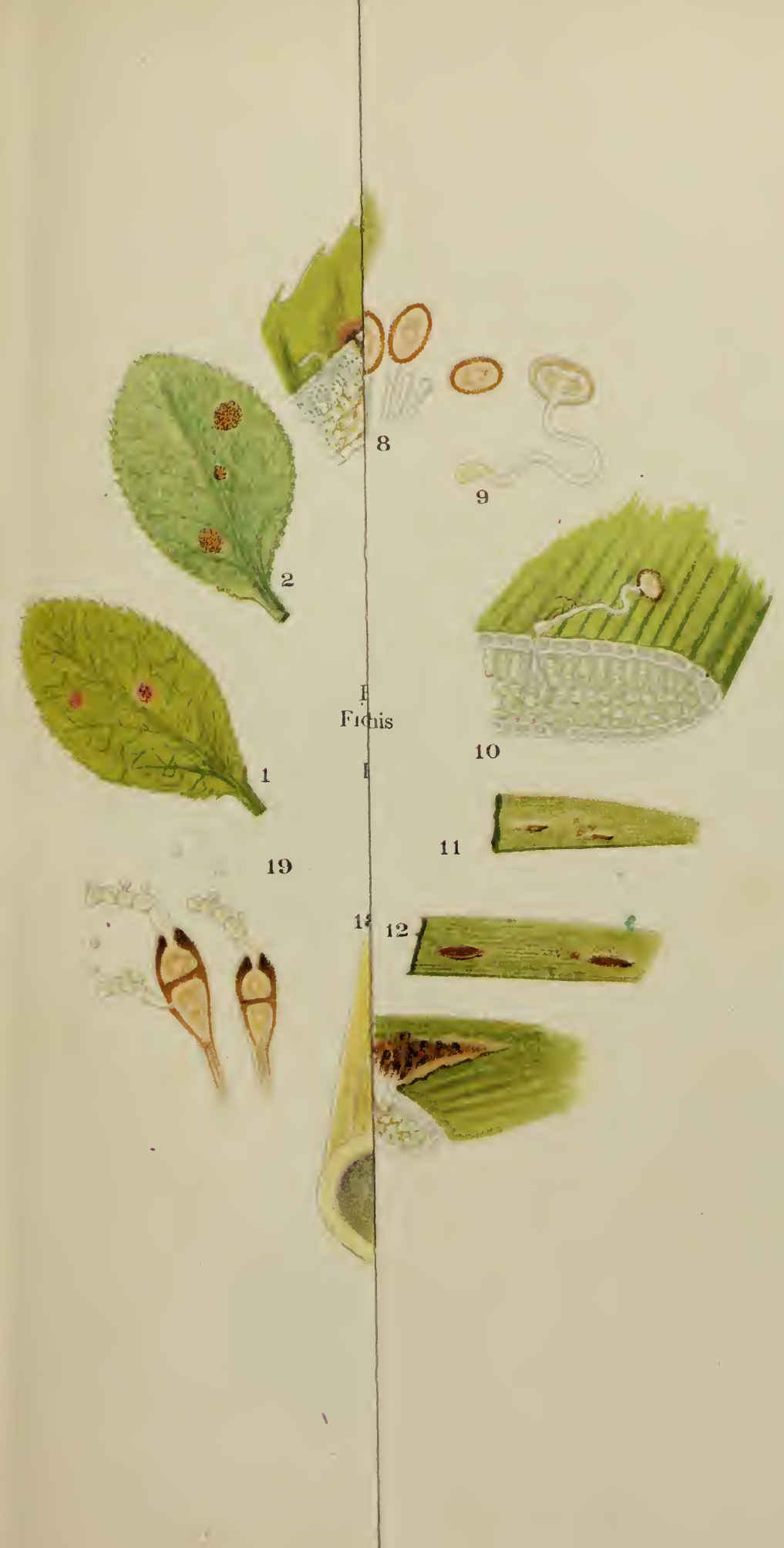




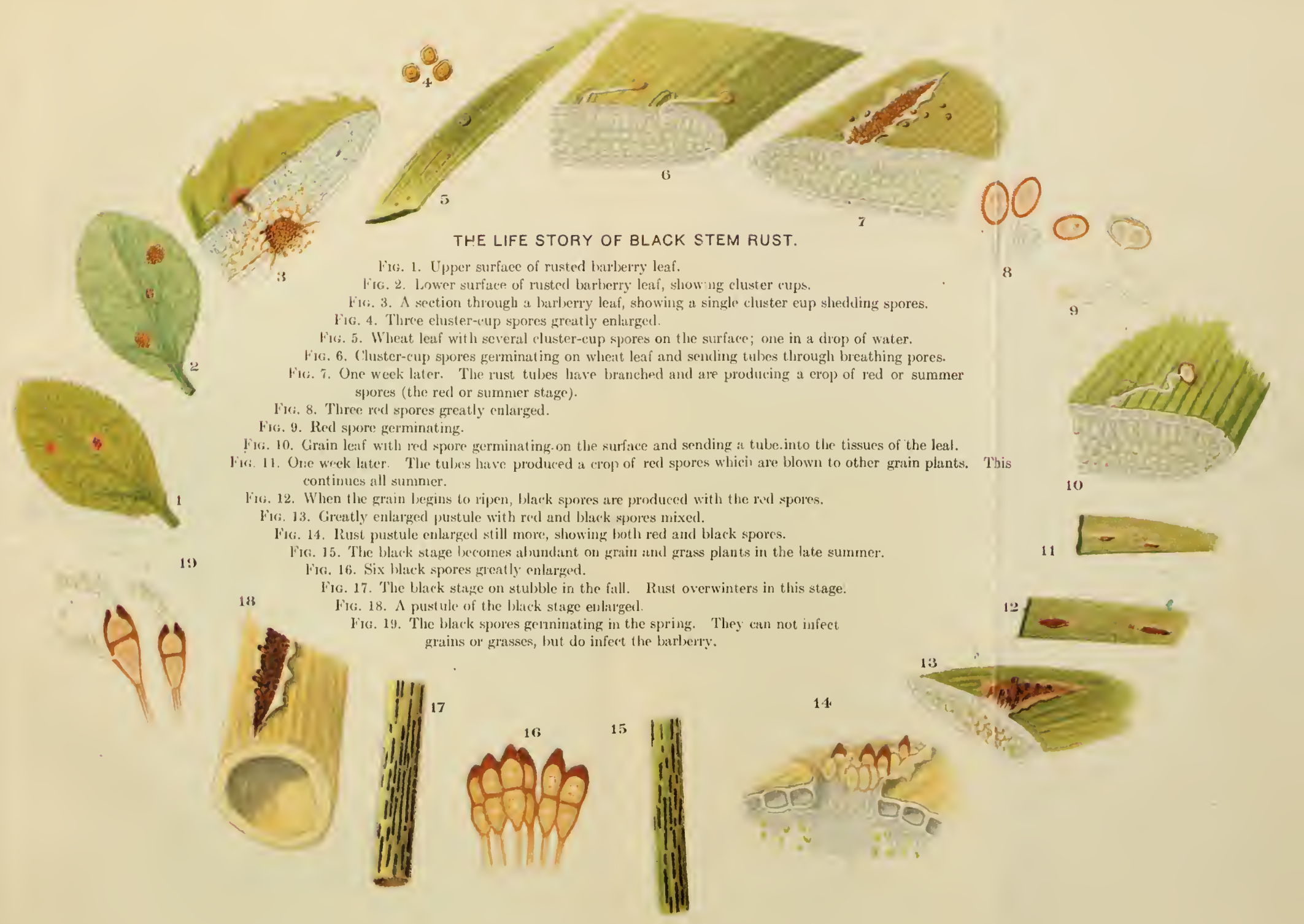




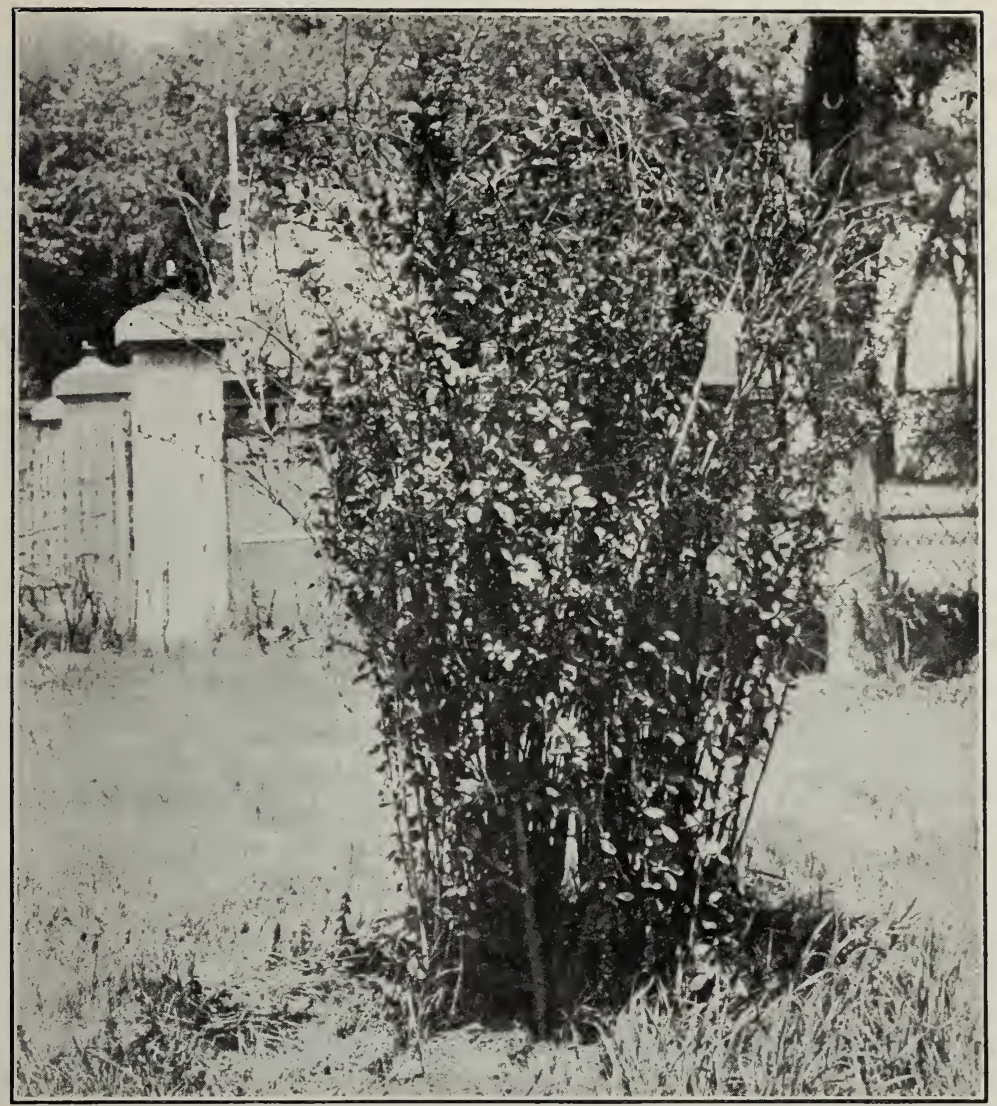

FIG. 1.-A COMMON BARBERRY BUSH, TALL AND ERECT. COMPARE WITH PLATE VI, FIGURE 1.

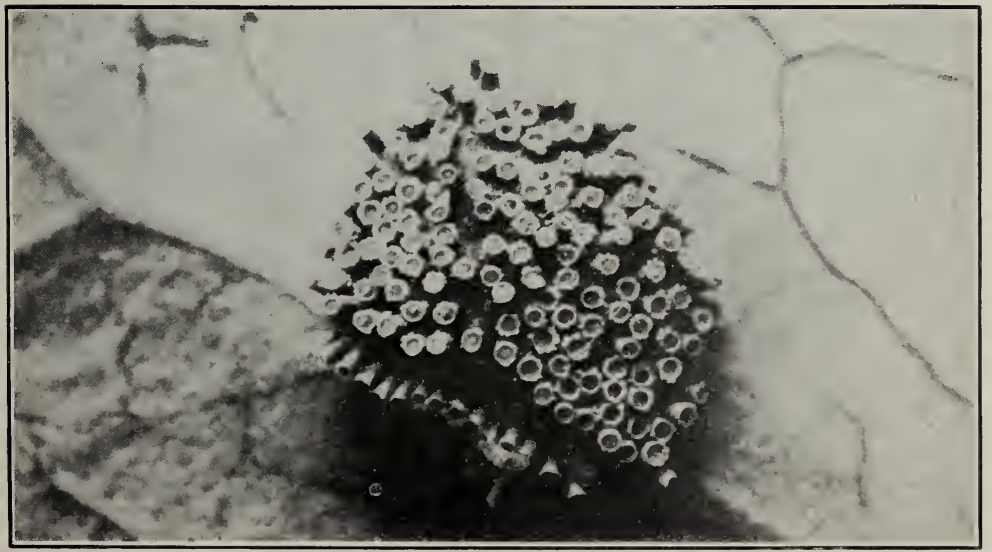

FIG. 2.-A PORTION OF A BARBERRY LEAF, GREATLY ENLARGED, SHOWING CLUSTER CUPS WHICH CONTAIN THE SPORES. 


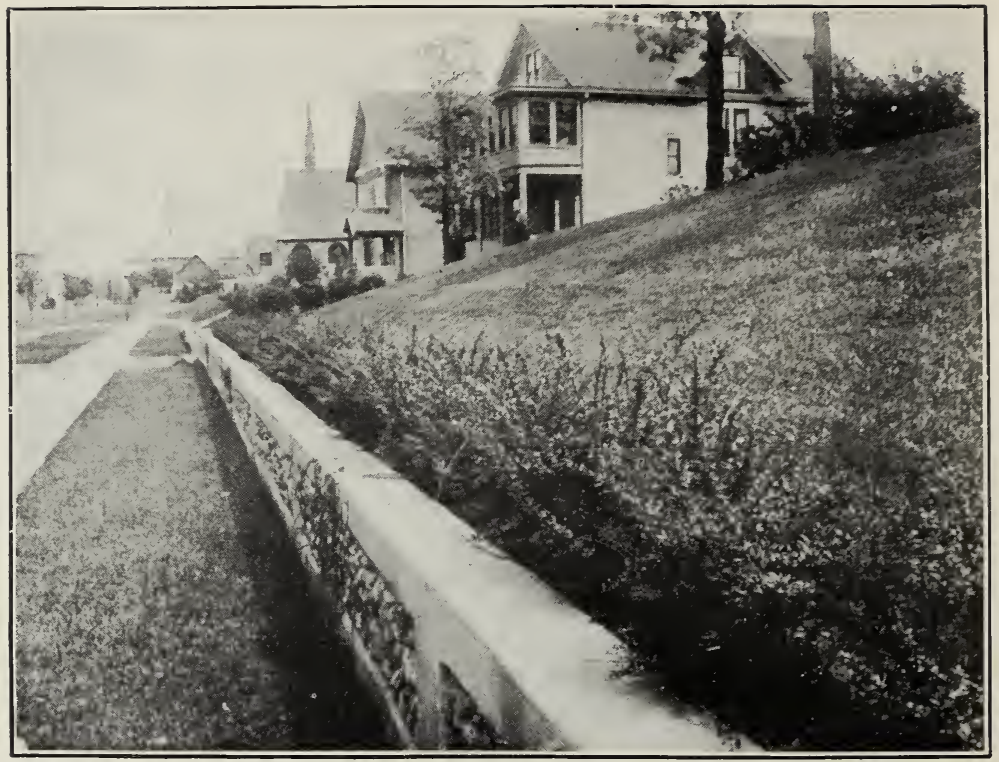

FIG. 1.-A HEDGE OF JAPANESE BARBERRY, LOW AND SPREADING GRACEFULLY. COMPARE WITH PLATE V, FIGURE 1.

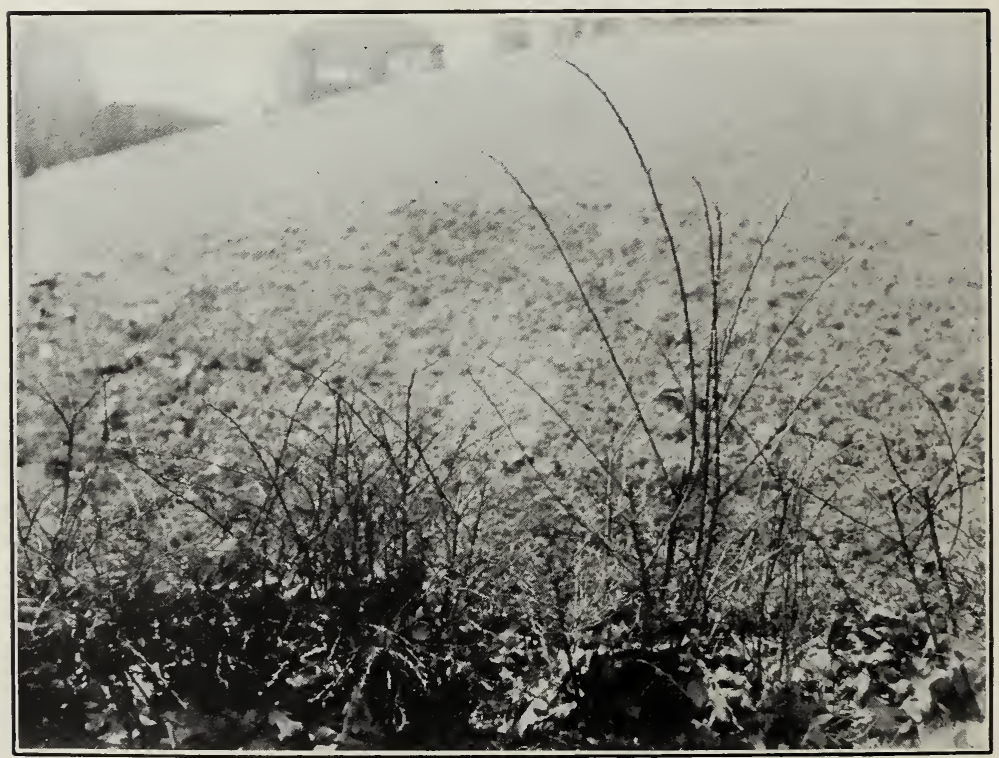

FIG. 2.-ONE COMMON BARBERRY BUSH IN A HEDGE OF JAPANESE BARBERRY. IT IS EASILY RECOGNIZED BY ITS HEIGHT. 
duced. The entire time from the germination of a spore to the production of a pustule may require only 5 or 6 days when conditions are favorable. The red stage of the rust may repeat every week or 10 days and therefore can increase and spread very rapidly. New spores may continue to develop and new plants may become rusted as long as the weather is favorable and the plants are still green.

The black-spore stage follows the red-spore stage. It is usually formed when the grain begins to ripen. The same dense network of threads which produced the red spores begins to produce the black spores, which are different from the red spores in size, color, and shape (Pl. IV, figs. 8 and 16). At first the pustules may be partly black and partly red (Pl. IV, fig. 12) because they contain both red and black spores (Pl. IV, figs. 13 and 14), but later they become entirely black. This black stage is so conspicuous that farmers usually speak of the rust as "black rust" (Pl. IV, fig. 15). The black spores (Pl. IV, fig. 16) are not blown by the wind and can not germinate immediately, but remain on the straw and stubble of grains and grasses during the winter ( $\mathrm{Pl} . \mathrm{IV}$, figs. 17 and 18). The black stage can not start rust on grains or grasses, but only on the barberry.

In the spring the black spores germinate by sending out two threadlike tubes on which very small colorless spores (sporidia) are produced (Pl. IV, fig. 19). These sporidia are blown considerable distances by the wind. Strangely enough, they can not start rust on grain or grass plants, but can and do infect the common barberry. The result is the barberry rust or spring stage of black rust. Within a week or 10 days after a spore falls on a barberry leaf and causes infection, small honey-colored spots are formed on the upper surface of the barberry leaves and a great many cluster cups are formed on the lower surfaces. (See Pl. IV, fig. 2, and Pl. V, fig. 2.) The cluster cups are filled with thousands of spring or cluster-cup spores, which can not attack other barberries, but can attack grain and grasses. These spores are blown by the wind, fall on grains and grasses, germinate in a drop of dew or rain water, and each sends a tube into the tissues of grain or grass plants. These tubes grow and branch and produce a crop of the red spores within a week or 10 days. 
The cycle is therefore as follows: The rust starts on the common barberry in the spring, forming the spring or cluster-cup stage. The barberry or cluster-cup stage can not spread from one barberry bush to another, but spreads to grains and grasses. The red-spore or summer stage results. The red stage continues to develop and spread as long as conditions are favorable. Late in the season the red stage is followed by the black stage. The black spores are dormant during the winter, but germinate and produce smaller spores, which in the spring attack the barberry.

It is evident, therefore, that the barberry gives the rust a chance to start in the spring and that the black spores are harmless unless there are barberry bushes near by. The question remains whether there are still other ways in which the rust can live through the winter.

\section{HOW DOES RUST LIVE OVER WINTER?}

There has been a popular belief that the rust lives over winter in the seed or in the red stage, as well as in the black stage. Considerable work has been done to determine just how the rust lives through the winter.

\section{DOES THE RUST LIVE IN THE SEED?}

There has been a belief among some people that the rust lives over winter inside the seed and then attacks the sprouting plants. If this were true it would be possible to control rust somewhat by selecting seed from unrusted fields. Furthermore, one serious rust year would likely be followed by another bad rust year. But two bad rust years seldom occur in succession, except in some regions where the rust probably develops during the entire year. If the rust lived in the seed during the winter, the sowing of rusted seed ought to result in the development of rusted plants. Carefully made experiments have shown that the rusted seed does not produce rusted plants. Hundreds of examinations of sprouting seeds show that the rust on the seeds does not infect the young sprouts.

\section{DOES THE RED STAGE LIVE OVER WINTER ?}

For the past two years the Department of Agriculture has been studying the question of the overwintering of the redspore stage. It is well known that the leaf rusts overwinter 
in the red-spore stage. It has been shown clearly that the black stem rust does not overwinter commonly in the redspore stage except in the extreme South and on the Pacific coast, where the rust can continue to develop on fall-sown grains practically throughout the winter. Thus, in the Gulf States and in California the red stage of rust can continue to develop practically the year round. However, it is perfectly clear that the rust does not overwinter commonly in the red-spore stage except in the extreme South, on the Pacific coast, and in some protected mountain valleys. Experiments in the winter of 1917-18 prove conclusively that the red stage did not live through the winter as far south as Jackson, Tenn. It was shown also that the rust did not overwinter in the red-spore stage in Oklahoma, Kansas, Missouri, Kentucky, Nebraska, or in any of the States farther north. All the evidence available at present shows that if the red stage of rust does live through the winter at all in the Northern States, it does this so rarely as to be of little importance in starting rust epidemics.

The question naturally arises whether the rust spores which overwinter in the South could not be blown northward in the spring and infect the growing grain. In this way the rust might travel from south to north by successive stages as the crop develops. Evidence based on careful observations shows quite clearly that this does not occur. The rust develops on barberry plants in the North and spreads to grains and grasses quite as early in the spring as the rust begins to become general in the South. Then, too, the form or race of wheat rust which is common in the South can not cause rust on hard spring wheats or on most of the hard winter wheats of the North. Even if the rust did blow up from the South, therefore, it could do very little damage in the North.

THE OVERWINTERING OF THE BLACK SPORES.

In the Gulf States the weather is mild enough to enable the red spores to live through the winter, but in the upper Mississippi Valley only the black spores live through the winter to any extent. In the spring they germinate and infect the barberry. The rust spreads from the barberry to grains and grasses and continues to spread as long as 
weather conditions are favorable. Field observations show clearly that in the northern half of the Mississippi Valley the barberry gives the rust its start in the spring.

\section{CONDITIONS WHICH FAVOR RUST DEVELOPMENT.}

Weather affects the development of rust in several ways. It is plain that if rust is to develop and spread, the red or summer spores must be blown from plant to plant. Strong winds carry the spores long distances and therefore enable the rust to develop over a wide area. But even though the spores have been scattered widely they will not germinate unless the conditions of moisture and temperature are favorable. Heavy dews and fogs or steady, quiet rains furnish the best conditions for spore germination and consequently for rust infection. Heavy driving rains are probably not so favorable for infection, because they wash many of the spores from the plants on which they have fallen.

After the rust parasite has entered a plant it will develop most rapidly when the weather is rather hot and muggy. At low temperatures the rust develops much more slowly, and it may also be checked by hot, dry weather. The weather also may be favorable for infection but not for rust development after infection. Or it may be favorable for the growth of rust at one time during the season and not at another. When the right conditions occur at just the right times epidemics develop.

The variety of grain grown and the condition of the plants affect the rapidity of the growth of the rust parasite. Soil conditions influence rust development in so far as they affect local conditions of moisture and temperature and the growth of the grain plants.

\section{HOW TO REDUCE RUST LOSSES BY CULTURAL METHODS.}

Rust can not be prevented entirely, but the losses which it causes can be reduced. Proper soil management, early sowing, the use of early-maturing and resistant varieties, the destruction of weed grasses which can be attacked by rust, and the eradication of the common barberry all will aid in reducing rust losses. 
SOIL MANAGEMENT.

Grain grown on high land usually does not rust as severely as that grown in low places. On account of poor air drainage, moisture remains on the plants longer in the low places, and the rust therefore has a better opportunity to develop. Whenever possible, high, well-drained land should be selected for grains in those regions in which rust is destructive.

Every possible means for hastening the ripening and the even development of the grain should be used. Rust develops most rapidly fairly late in the season, and early ripening often enables the grain to escape rust injury. The preparation and fertilization of the land are quite important. The seed bed should be prepared very thoroughly, in order that the plants may get a quick start.

The problem of proper fertilizing differs in different regions. In general, it is safe to say that the use of large quantities of nitrogenous fertilizers, especially on those soils which do not need them badly, will permit greater rust damage. Although the actual amount of rust may not be any greater on the plants fertilized with nitrogen, reduction in yield is almost certain to occur. The straw of plants fertilized heavily with nitrogen is often weak and crinkles badly when rust attacks it. The ripening also often is delayed, and the rust therefore has a longer time in which to spread and cause damage. As far as possible, while giving the plant what it needs, those fertilizers should be used which promote the development of stiff straw and cause early ripening. Plants fertilized with potassium or phosphate fertilizers usually yield better in bad rust years than those which have been fertilized with nitrogen.

EARLY SEEDING OF GRAIN.

The later the grain remains green the more chance the rust has to attack it. Anything therefore which can be done to hasten the ripening of the grain should be done. It is quite clear that early seeding, particularly of spring wheat, on a very well prepared seed bed and in soil which has been properly fertilized will cause the plants to develop rapidly 
and reach maturity before the rust becomes widespread. It is a matter of common observation that in severe rust years early-sown grain often develops much better than that sown later in the season. The most serious epidemics often reach their height of destructiveness two weeks before the grain ripens. A difference of a week or 10 days in ripening, therefore, may determine the difference between a good yield and practically no yield at all.

\section{EARLY VARIETIES OF GRAIN.}

An early-maturing variety grown on properly prepared land often will yield well when later maturing varieties yield practically nothing. The variety selected should depend on its adaptability to the region in which it is to be grown.

The yield of the grain is, of course, the real test. The Marquis is a spring wheat which is very susceptible to rust, but it matures a week or 10 days earlier than most of the other spring-wheat varieties and for that reason sometimes escapes serious damage. No general recommendation for the use of certain varieties can be made, but it is well to remember that, if two varieties are otherwise about equally valuable, the earlier maturing one should be given preference in a district in which rust is likely to be destructive.

\section{RESISTAN'T VARIETIES OF GRAIN.}

There is some hope of reducing rust losses by the use of rust-resistant varieties. More is known about the resistance of wheat varieties than about that of any other kind of grain. It has been known for many years that some varieties of wheat do not rust as heavily as other varieties under the same conditions. The durum wheats, as a group, have been considered fairly resistant to stem rust. Not.all varieties of durum wheat are resistant, but a great many of them are. This makes it possible to grow fairly good crops of some durum wheats when the bread wheats are injured severely by the rust.

Until recently no good bread wheat was known which was resistant to rust. A selection from the Crimean group made at the Kansas Agricultural Experiment Station several years ago, however, was tested for rust resistance and was found to be almost entirely immune under Kansas conditions. It 
seemed, therefore, that the rust problem in the winter-wheat regions might be near solution. However, it has since been found that there are many races or forms of wheat rust. They differ from each other chiefly in their ability to attack different varieties of wheat. Some of the varieties of durum wheat which are quite resistant to rust forms in many localities are quite susceptible to the forms of rust occurring in other localities. In the same way, some varieties of hard spring wheat which rust most heavily in the spring-wheat region do not rust severely when grown in the extreme South. The Marquis and Haynes Bluestem were grown in the South and were almost entirely free from rust, while the native soft winter wheats in that region were rusted heavily. In the same way, the resistant Kansas variety, Kanred, was very resistant when grown in Kansas but rusted in some other parts of the United States.

No one variety now known is resistant to all the forms of rust which occur in the United States. No one rustresistant variety of wheat, therefore, can be recommended for universal use. The problem is a local or regional one, and varieties should be selected with this in mind. As no general recommendations can be made, it would be well to consult your State agricultural college before sowing a supposedly rust-resistant variety.

It is perfectly clear, however, that rust resistance alone should not commend a variety of wheat for general use. It must combine other desirable characters with its rustresistant quality. For this reason much crossing and selecting have been done to combine the rust-resistant character of some varieties with the high-yielding and good thrashing and milling qualities of other varieties. Some success has been attained, but not enough progress has been made to give any hope that the rust problem may be solved entirely in this way in the near future. Until it is known how many races of the stem rust there are, where they occur, and which varieties they can attack, relief by means of resistant varieties will be local or regional. Investigation of this character is being carried on by the United States Department of Agriculture in cooperation with several State agricultural experiment stations, and it is hoped that within a few years valuable information will be available. 
ERADICATION OF WEED GRASSES.

Many wild grasses are dangerous carriers and spreaders of stem rust. Among those which rust most commonly and heavily are quack-grass, wild barley or squirrel-tail grass, slender wheat-grass, western wheat-grass, the wild ryegrasses, and orchard grass. Some of these grasses are bad and widespread weeds. Where they grow near barberries they almost always rust heavily early in the spring and then serve as centers of infection, from which the rust spreads to other grasses and then to grainfields. The rust-carrying grasses are so common that, together with the grains, they constitute what is in fact a continuous grainfield in many sections of the country. From the standpoint of good farming they should be kept down as much as possible by clean cultivation. Grasses growing along roadsides, fences, and in waste lands are a continual menace. They continue to develop rust after grain has been cut and so provide more rust from which to start epidemics the following spring. It is to be hoped that in the near future unused lands will be put under cultivation as much as possible. Every available means should be taken to destroy these weed grasses, because they spread rust in addition to the injury they cause as weeds. It is impossible to control rust by this method alone, but the general eradication of the weed grasses no doubt would reduce the amount of rust considerably.

\section{ERADICATION OF THE COMMON BARBERRY TO REDUCE RUST LOSSES.}

No one of the methods just discussed will prevent rust entirely, nor can a combination of all of them be depended. on to do more than reduce somewhat its amount and destructiveness. The eradication of the common barberry and other rust-carrying species and varieties of barberry gives more promise of success than any other one control measure. The eradication of the barberry can not be urged too strongly; but the difference between harmful and harmless kinds, the parts of the country in which they are most important, and the results to be expected by removing them should be understood. 


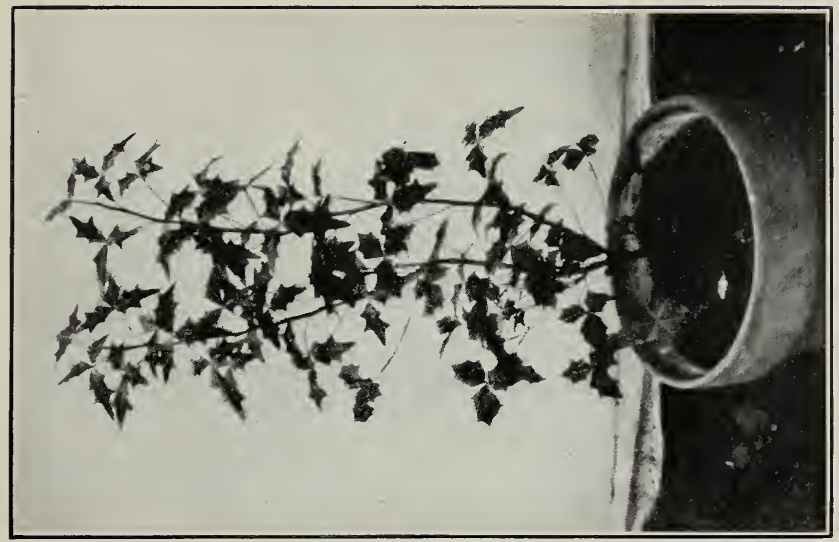

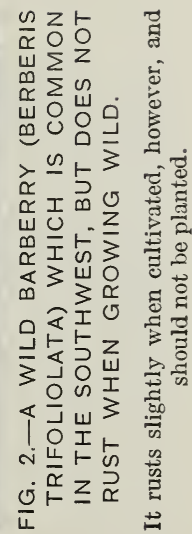

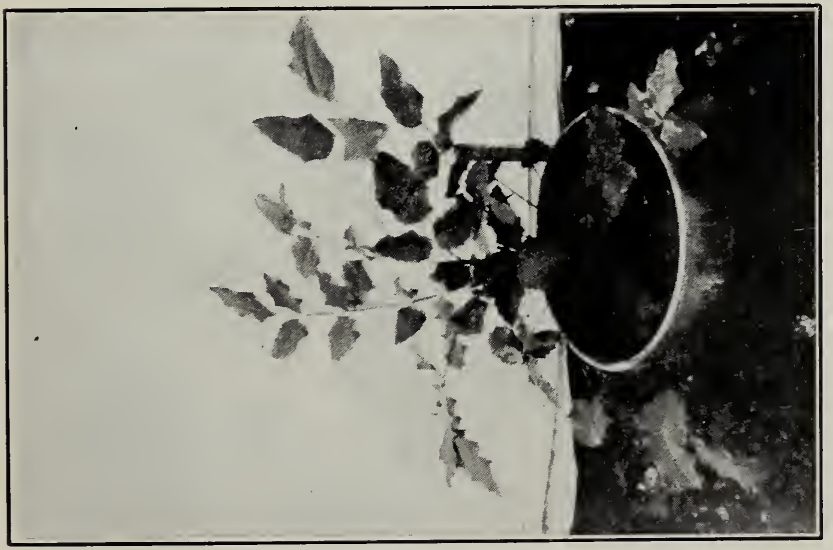

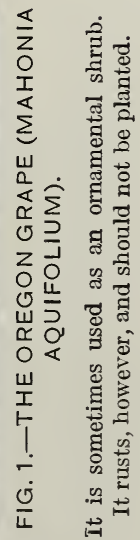




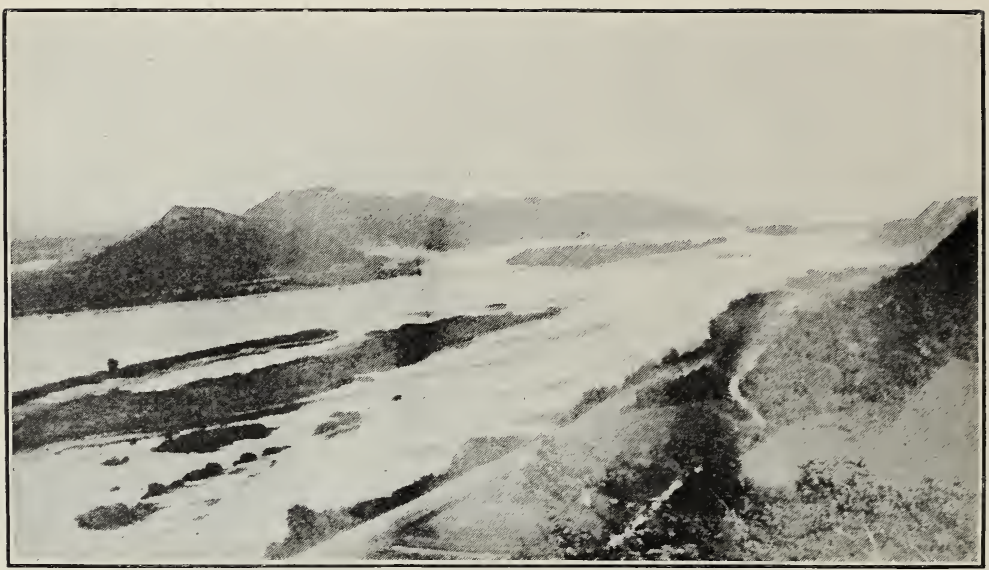

FIG. 1.-BLUFFS NEAR THE MISSISSIPPI RIVER BETWEEN WINONA, MINN., AND TREMPELEAU, WIS., ON WHICH ESCAPED BARBERRIES HAVE BEEN RUNNING WILD FOR 30 YEARS.

The bushes are up high where the wind scatters the spores for miles around. They are being located and dug.

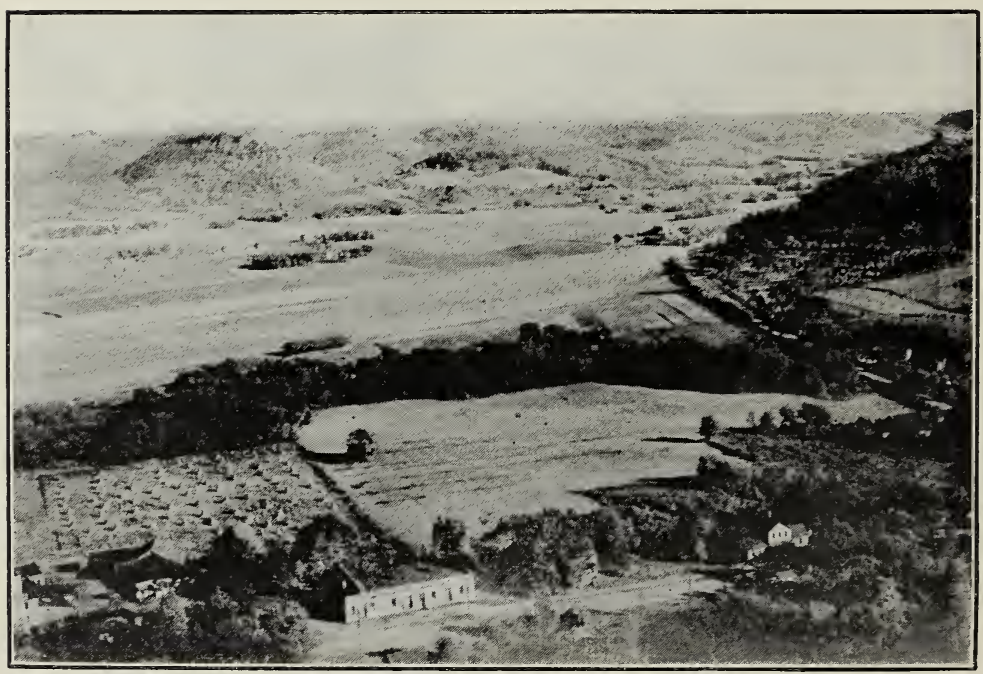

FIG. 2.-BLUFFS ALONG THE MISSISSIPPI RIVER WHERE BARBERRIES HAVE BEGUN TO RUN WILD AND THREATEN DANGER TO THE CROPS IN THE VALLEY BELOW. 
HARMFUL AND HARMLESS BARBERRIES.

Not all barberry species and varieties are harmful. The common European or high-bush barberry (Berberis vulgaris) is the commonest offender (Pl. V, fig. 1). The purpleleaved barberry is only a variety of the common barberry and rusts just as badly as the green-leaved form. The Japanese barberry (Pl. VI), also called the dwarf or low barberry (Berberis thunbergii), on the other hand, does not rust and should not be disturbed, because it not only is harmless but is also a very beautiful shrub. Various species of Mahonia (Pl. VII, fig. 1) also rust, but these bushes are not so commonly planted and are not so important in the development of rust as the barberry bushes. (See Pls. V, VI, and VII.)

There are many species of barberry, both harmful and harmless, but it can be stated that, as a general rule, those which resemble the common barberry carry rust and those which resemble the Japanese form do not. The two forms sometimes hybridize and the hybrids may rust even when they look almost exactly like the Japanese variety. A list of rust-susceptible and rust-resistant barberries is given later.

The two types of barberry can be distinguished from each other very easily. While it is easiest to tell them apart when the leaves are on the bushes, the presence of leaves is not at all necessary. They can be distinguished by their different habits of growth, the color of the bark, the number of the spines, and the grouping of the berries.

The common barberry (Berberis vulgaris) is a tall, erect shrub, often as much as 12 feet high. The bark is grayish in color, and there are spines along the stem (fig. 1). These spines are usually in groups of three or more, although sometimes only one or two occur. The leaves occur in clusters, are green or purple in color, and have saw-tooth edges (fig. 1). The yellow flowers and red berries are in long, drooping racemes like those of currants (fig. 1). The flowers are small and inconspicuous, but the red berries are numerous and easily seen, usually remaining on the plants throughout the winter. (See Pls. V and VI.)

The Japanese barberry (Berberis thunbergii) is a low, gracefully spreading shrub, seldom more than 4 or 5 feet tall. 


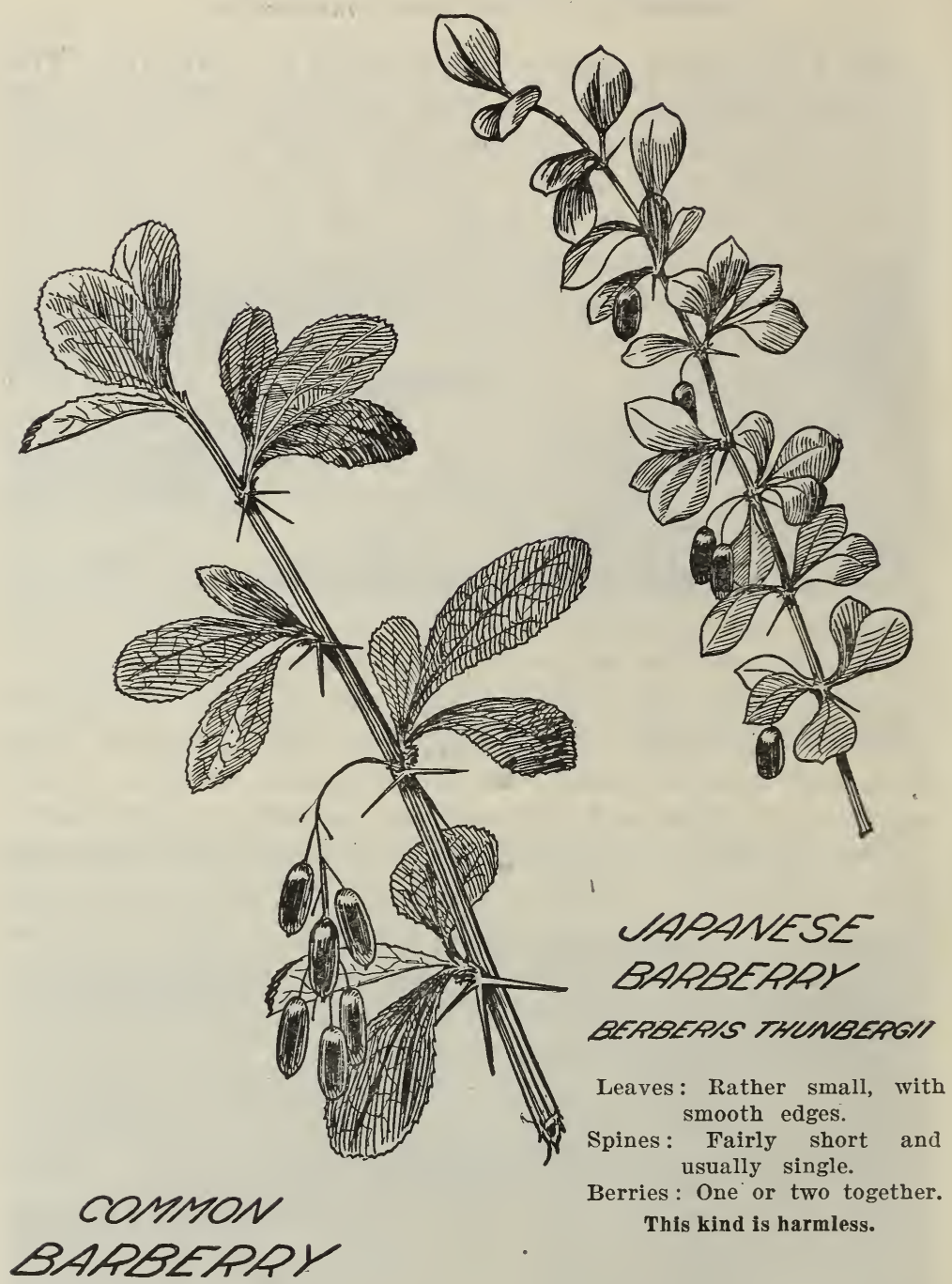

\section{BEPBEPIS VULGAPIS}

Leaves: Fairly large, with saw-tooth edges. Spines: Long, and usually in groups of three. Berries : In clusters like currants. .

This kind spreads rust.

FIG. 1. - The common barberry and the Japanese barberry, showing the differences. 
The bark is reddish in color and the spines (fig. 1) are smaller than those of the common form. They are usually single, but sometimes in twos and threes. The cdges of the leaves have no teeth. The flowers are yellow and the berries are red, like those of the common form. But both the flowers and the berries are in very small bunches of two or three, like gooseberries, and not like currants (fig. 1). (See Pl. VI.)

Mahonia (Mahonia spp.) is a shrub with leaves somewhat resembling those of the common holly. The leaves are compound (that is, composed of several leaflets, like those of a pea), rather large and stiff, often with spines along the edges. The berries are blue. - (See Pl. VII, fig. 1.)

The following list summarizes what is known now about the relation of different kinds of barberry and rust.

\section{LIST OF BARBERRIES AND RELATED PLANTS.}

The following species and varieties are known definitely to rust, although they do not all rust equally severely:

Berberis aetnensis, altaica, amurensis, aristata, asiatica, atropurpurea, brachybotrys, brevipaniculata, buxifolia, canadensis, caroliniana (carolina), coriaria, cretica, declinatum, fendleri, fischeri, fremontii, heteropoda, ilicifolia, integerrima, laxiflora, lycium, macrophylla, nepalensis, neubertii, sieboldii, siberica, sinensis, trifoliolata, umbellata, vulgaris, vulgaris atropurpurea, vulgaris emarginata, vulgaris japonica, vulgaris purpurea, vulgaris spathulata.

Mahonia aquifolium, diversifolia, glauca, repens.

The following forms of the common barberry may rust, but this is not certainly known:

Berberis vulgaris alba, vulgaris asperma, vulgaris fructiviolacea, vulgaris lutea, vulgaris macrocarpa, vulgaris mitia, vulgaris nigra, vulgaris violacea.

The following barberries are known not to rust:

Berberis thunbergii (Japanese barberry) and its varieties maximowiczii, minor, pluriflora, and variegata.

It is not known definitely whether the following rust or not. Some of them very probably do, while it is almost certain that others do not.

Berberis actinacantha, angulosa, brachypoda, congestiflora, coryi, crassifolia, darwinii, diaphana, dictyophylla, empetrefolia, fortunei, francisci-ferdinandi, gagnepainii, guimpelii, heterophylla, jamiesonii, levis, linearifolia, lucida, macrophylla, nana, nervosa, pearcii, pinnata, prattii, pumila, regeliana, sargentiana, spinolusa, stenophylla, subcauliolata, thibetica, trifolia, verruculosa. 
DISTRIBUTION OF THE BARBERRY.

The common barberry is a native of Asia and was brought into Europe 400 or 500 years ago. It was cultivated as a fruit bush for hundreds of years until it was found to spread the rust of grains. The berries were used for preserves and jellies, and their juice was used for making wine and vinegar. The early colonists brought the bush to North America, and it has been more widely distributed year by year, although recognized as a menace to our grainfields. The bush was popular and the colonists carried the seeds or the bushes themselves with them when they went into new regions. Barberry bushes were planted around the first cabins which the settlers in the Middle West built. There are thousands of bushes in that section which are 40 or 50 years old. Many bushes as old as 60 or 70 years are still thriving. The settlers unknowingly brought with them the greatest enemy to their grain crops. The barberry was there as early as the grain. Nurserymen have been propagating and distributing barberry bushes for many years, although they have discontinued this practice to a considerable extent since they have learned its relation to the rust of wheat and other grains.

The barberry is especially common in cities, villages, and even in the country districts in the New England States and westward through the upper Mississippi Valley. It is very common in parks, cemeteries, and on public and private grounds, where it has been used in hedges and in clump plantings. Scarcely a village or city of any size in the upper third of the country is without some barberry bushes. The bush is not nearly so popular in the South. Naturally the barberry problem is much more serious in those regions where the bushes are most abundant.

THE COMMON BARBERRY RUNNING WILD.

The seeds of the barberry are carried by birds, and the bush has escaped from cultivation to some extent in this way. In the New England States large numbers of common barberry bushes are found growing wild in pastures and fields. Fortunately those States are not primarily grain-growing States or their problem would be discouraging indeed. But the barberry has escaped also to some extent in the grain-growing 
districts of the Middle West. In Michigan, Wisconsin, Iowa, Minnesota, and other grain-growing States some wild bushes occur, although they are not so numerous as to make their eradication impossible. But one trembles to think of the effect on the great grainfields which furnish us our food if the barberry is allowed to go on spreading until it becomes common in the open fields. The wild bushes which do occur now are mostly along the banks of rivers or on rocky hills (Pl. VIII), especially where there is limestone. Of course, the spreading of the bush in these rocky places makes it all the more, dangerous, because it is hard to kill when it has established its root system in the crevices of the rocks.

NATIVE BARBERRIES.

There are also several sorts of native barberry. These occur in the southern Appalachian region, in the States of the southern Great Plains area (Pl. VII, fig. 2), and in the Rocky Mountains. Some of them are susceptible to rust, but on account of their location and the fact that some of the commonest kinds do not rust easily, they seem to be of very little or no importance in developing rust. The presence of these sorts, therefore, does not constitute an argument against the eradication of the common barberry, which has been shown time after time to spread rust. All the evidence now indicates that the native barberries do not play an important part in the development of rust epidemics. However, some of the native kinds will rust severely when planted in regions in which grains are grown commonly, and they should not be planted.

\section{HOW SEVERELY DO BARBERRIES RUST?}

Barberry bushes rust much more commonly and heavily in the Northern States than in those farther south, although rusted bushes have been found as far south as central Tennessee. They apparently rust quite generally in northern Missouri and northern Kansas, but they are more generally and severely rusted in Nebraska, Iowa, Colorado, and the States farther north. However, it is safe to say that common barberry bushes when near grainfields may be dangerous even in the South. 
The amount of rust on the barberry depends largely on weather conditions and the proximity of grains and grasses. When the weather in the spring is moist and warm the bushes may rust heavily. Usually they begin to rust early in May and may continue to become rusted throughout the entire growing season. Rust has been found on them as late as October. They may therefore continue to spread rust during this entire period. Rust develops not only on the bushes near grainfields but also on those in villages and cities. Barberry bushes develop an enormous amount of rust, and this rust spreads destruction to wheat and other grains.

\section{THE SPREAD OF RUST FROM THE BARBERRY.}

It is a matter of common observation that the rust spreads quickly from barberry bushes to the grains and grasses in the immediate vicinity (Pl. IX). The spores from the barberry are carried by the wind, and within a week from the time the rust first appears on the bushes the grains and grasses within a few rods of the bushes begin to rust. As far north as Minnesota and Wisconsin susceptible grains and grasses near the rusted barberry bushes are often red with rust by the middle of May. These red spores are carried many miles by the wind, and the rust from the first rusted grasses and grains can infect those at considerable distances. Then infection spreads from these plants to others, and thus the rust travels by successive steps. In this way the effect of a single bush often extends for many miles.

The following typical cases show more clearly the effect of barberry bushes on grains. Hundreds of similar cases could be cited. Practically all of the barberry bushes which caused the damage have been dug. Fourteen farmers in Indiana saw so clearly the effect of the barberry on wheat rust that they made the affidavit which is given here with names omitted:

We, the undersigned farmers of Wabash County, Indiana, at a meeting at the farm, in Noble Township, on July 19. 1918, called for the purpose of observing the ravages of the black stem wheat rust on the 17-acre wheat field, desire to go on record as follows:

1. We are fully convinced after making these observations that there is a connection between the common barberry and the black stem wheat rust. On the south side of this ruined field is a large planting of common barberry bushes which have been badly infected 


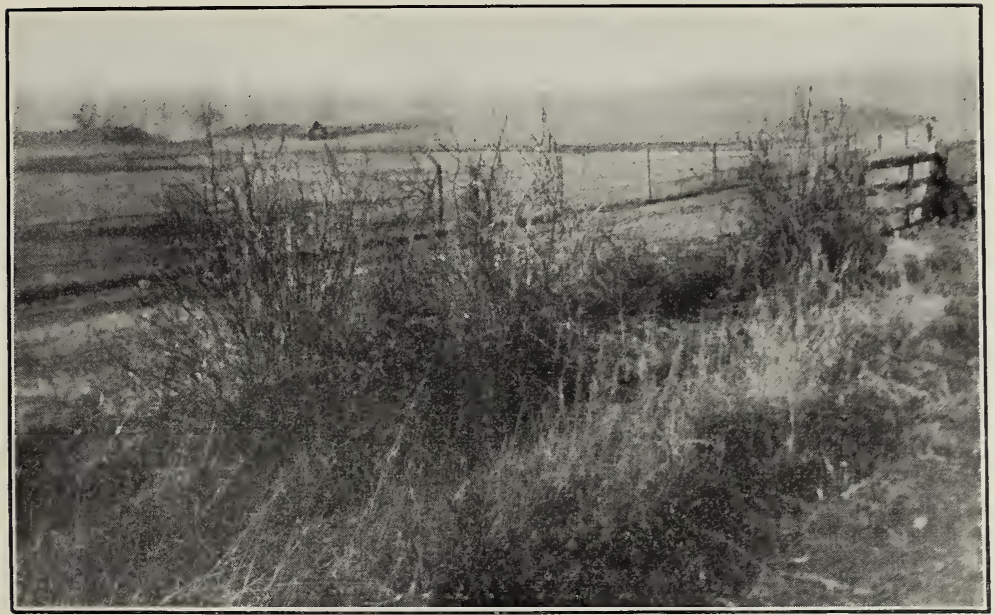

FIG. 1.-OLD NEGLECTED HEDGE OF COMMON BARBERRY SURROUNDED BY GRASSES WHICH RUST HEAVILY EVERY YEAR AND SPREAD THE RUST TO NEIGHBORING GRAIN FIELDS. THESE BUSHES HAVE BEEN DUG.

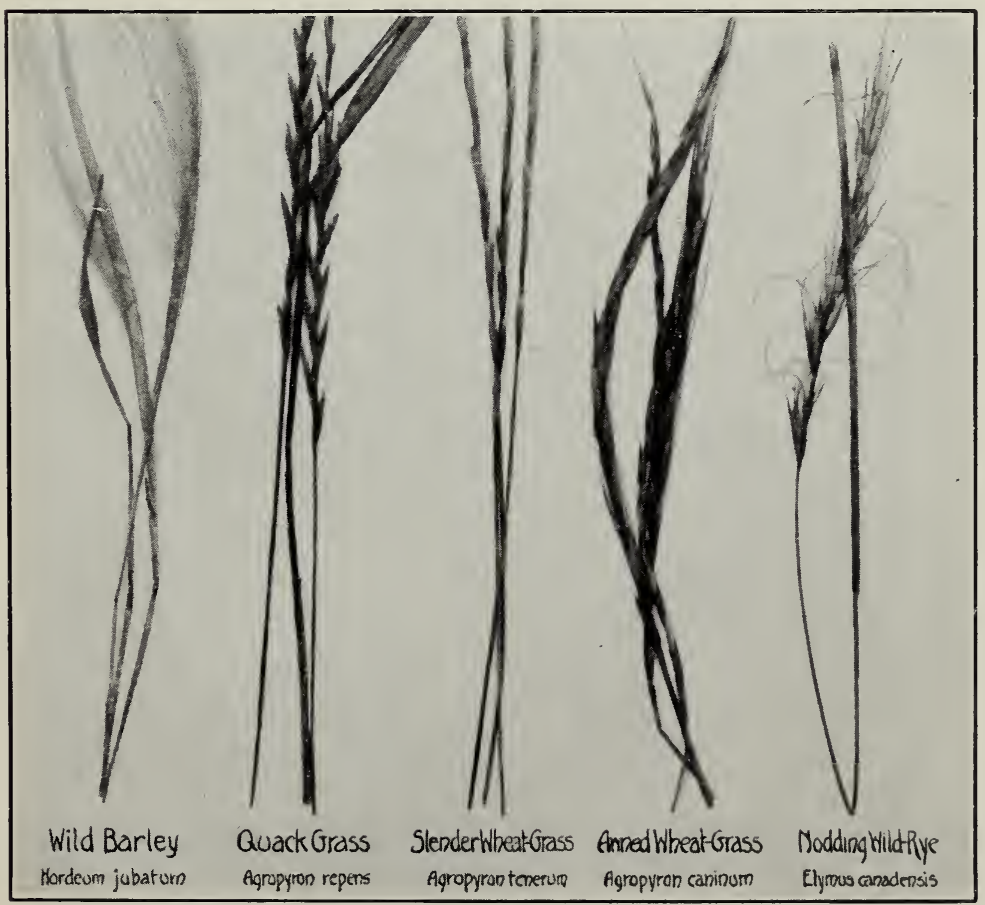

FIG. 2.-SOME COMMON WILD GRASSES WHICH RUST HEAVILY.

The rust can spread from these grasses to grain as well as from grain to other grains. 


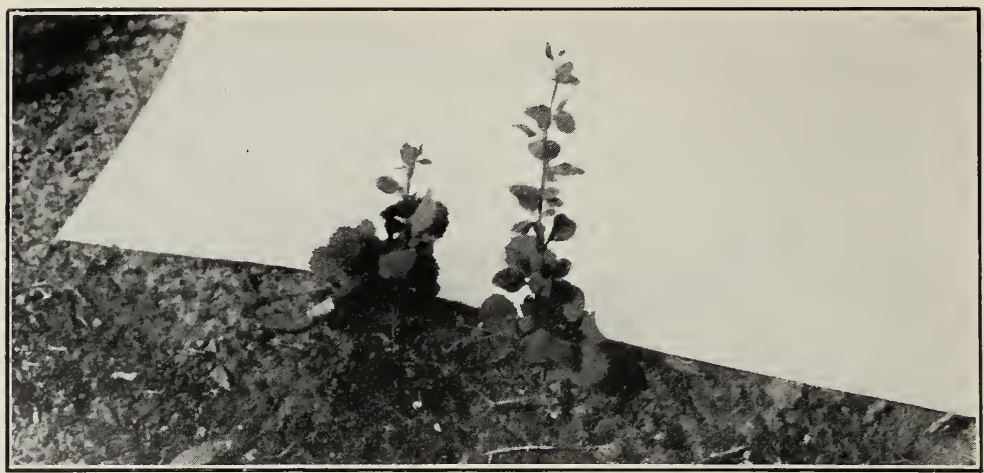

FIG. 1.-THESE SPROUTS OF COMMON BARBERRY GREW FROM PIECES OF ROOTS LEFT IN THE GROUND WHERE A BUSH WAS DUG. DIGGING MUST BE COMPLETE AND THOROUGH.

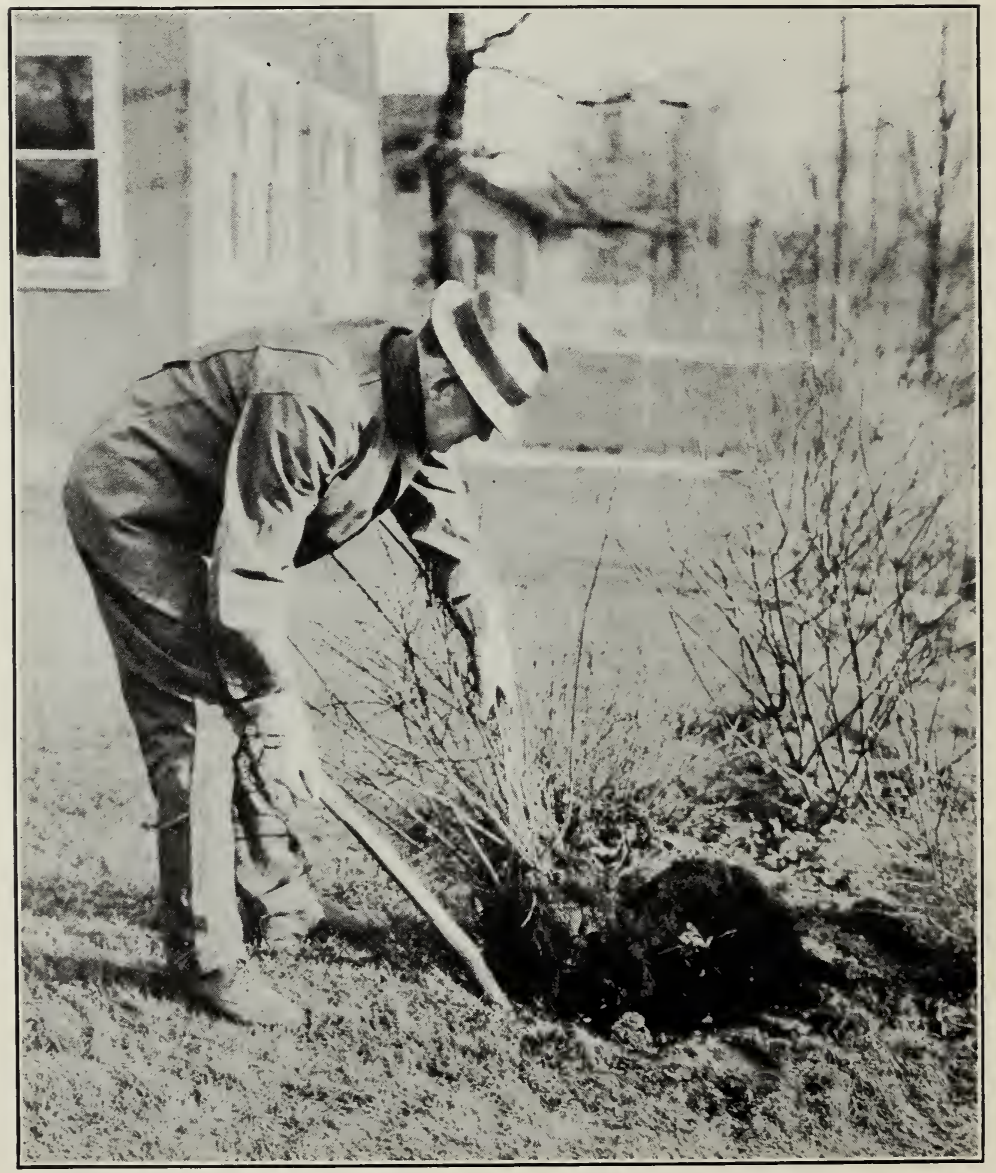

FIG. 2.-THE PROPER WAY TO REMOVE BARBERRY BUSHES. DIG DEEP ENOUGH TO GET ALL OF THE ROOTS. 
by the rust. We have observed that the rust started on the side of the field next to these bushes and that now the worst infestation is on the side nearest the barberries.

2. We desire to go on record as favoring any legislation looking toward the complete eradication of the common barberry bush, believing it to be of no value, but, on the other hand, a serious menace to the wheat-growing industry.

In Ohio several striking cases of the spread of rust from barberries were seen in 1918. The quotation given below illustrates one of them. There was scarcely any stem rust in the region except that which clearly came from the barberry.

In southwestern Green County, about 1 mile south of Bell Brook, Mr. — had a hedge of severely rusted barberry. He has 20 acres of wheat practically destroyed by stem rust. His neighbor, across the road, secured permission to put hogs on 20 acres of wheat that was so nearly destroyed by rust that it would not be worth cutting.

Near Lake Preston, S. Dak., common barberry bushes were scattered along the roadside for a distance of half a mile in a grain-growing region. Practically all the bushes were heavily infected with rust. The nearest grainfield was a field of barley about 400 feet west of the bushes, but there was a great deal of wild barley or squirrel-tail grass near the bushes. On July 20 the grass and grain were carefully examined. The weather had been hot and dry, and rust had not been spreading rapidly. In spite of the unfavorable weather, however, it was very clear that the rust had started from the bushes and had spread to the grasses, to barley, and to wheat fields within a distance of $2 \frac{1}{2}$ miles. Between July 20 and 30 there was a period of rainy weather. On July 30 the fields were again examined and the rust had developed so rapidly that the wheat was severely injured as far as $2 \frac{1}{2}$ miles from the bushes. The rust had spread to wheat fields 5 miles from the bushes. The effect of the bushes was so clear that 27 farmers drew up and signed the statement given below:

Since the common barberry harbors the black stem rust of the wheat in the early spring and thereby starts an early and serious infection of rust, particularly because of the barberries on two farms south of town which are known as the __ farms, where for many years early and serious stem-rust infection has been noted and is due to the presence of the barberries, we, the undersigned, believe that in 
order to protect the wheat crop of South Dakota from the rust infection caused by the common barberry, there should be a special barberry law in South Dakota making it a crime to propagate, grow, or have growing on any public premises any of the common rustsusceptible varieties of barberry.

During the summer of 1918 scarcely any stem rust appeared in Montana. The weather had been extremely dry and therefore unfavorable for rust development. However, several reports of severe stem-rust infection, sent to the Montana Agricultural College and the United States Department of Agriculture, showed that every one of the rust outbreaks that occurred in Montana during 1918 was directly traceable to infected barberries.

At Diamond Lake, Minn., a barberry hedge of 15 bushes was found heavily rusted on June 20,1918. The infection was traced from wild barley growing along the street to a wheat field located one-fourth of a mile northeast from the hedge. At this date the only stem rust in the wheat field was in the southwest corner, the part nearest to the hedge and infected grass. No rust was found in similar grass on the opposite side of the field. Thus, it was very evident that the barberry was responsible for the rust infection in the wheat field. The locality was visited again on July 25 , and at that time the rust was common throughout the field.

A farmer at Crystal Bay, Minn., had a barberry hedge of 635 bushes. He had tried to grow oats on his farm for the past 10 years, but each year the black stem rust destroyed almost all of the grain. In May, 1918, the farmer destroyed the barberry hedge before the bushes had become rusted. The field was examined thoroughly 10 days before harvest and no stem rust could be found. The yield was excellent and the quality of the grain good. This was the first time in 10 years that a crop had been grown successfully.

At Woodlawn Cemetery, Sioux Falls, S. Dak., there was a large hedge of the common barberry. These bushes became rusted early in the spring of 1918. A great deal of squirreltail grass grew near the barberry bushes, but the nearest wheat fields were three-fourths of a mile away. By July 22, in spite of weather unfavorable for rust, the rust had spread to the grass and from the grass to the nearest field of wheat, three-fourths of a mile away, and to other fields 1 mile away. 
The nearest field was very severely rusted, while the rust on those 1 mile distant was not quite so heavy. This shows clearly that barberry bushes in cities may cause rust on grains by going first to grasses and then to grains. The bushes have been destroyed.

\section{IMPORTANCE OF THE BARBERRY IN SPREADING RUST.}

There can be no question whatever that the barberry is the most important factor in the spread of rust in the northern half of the Mississippi basin. In the South it is less important.

There are large numbers of barberry bushes. They rust commonly, and the rust spreads from them directly to grains, or to grasses, and then from the grasses to grains. There are few grainfields in the Middle West which are more than 25 miles from a barberry bush. Rusted bushes were found in practically every county in Wisconsin in 1918. Barberry bushes were found in all but three counties in Minnesota, and these three counties were in the extreme north, where farm land is just beginning to be developed. Every county in Iowa contained the common barberry, and the same is probably true of every other Middle-Western State. About 95,000 bushes, exclusive of those in nurseries and those growing wild, were found in Wisconsin in 1918, while patriotic Minnesota nurserymen destroyed about 600,000 bushes, and at least 50,000 were located on private and public grounds. About 85,000 bushes were found during a preliminary survey of northern Illinois, and 25,000 were found east of the Missouri River in South Dakota. The bushes were numerous and commonly rusted also in North Dakota, Montana, Wyoming, Colorado, Nebraska, Michigan, Indiana, and Ohio. No systematic survey was made in other States, but it is known definitely that there are many bushes 'and that they rust heavily in the States near those just named. While most of the bushes are in cities and villages, they have also been planted fairly extensively in country districts. Long hedges were often growing as fences beside grainfields, and numerous smaller plantings were found. Barberry bushes rust early in the season and the cluster-cup spores may be blown considerable distances by the wind. But even 
if they were not blown far, the effect of a single bush could extend to grainfields miles away because the rust can spread from the bushes to near-by grasses or grains and then, in turn, to other grains and grasses. Since the rust may have started from the bushes by the middle of May, the amount of spread by midsummer can be very great.

Studies made up to the present show that the red stage of the rust does not persist commonly north of the Gulf States and that it does not spread from the south to the north. The first black stem rust which can be found in the Northern States in the spring always occurs near the leeward side of barberry bushes. The rust spreads from the bushes in the direction toward which the prevailing wind blows.

The barberry, therefore, enables the rust to start early in the spring, it increases the amount of rust, and in many regions of the country it furnishes the only means by which the rust can persist from one season to another and get an early start in the spring. The value of our grain crops is enormous; the value of the common barberry is as nothing in comparison. The Japanese barberry is harmless and is more beautiful than the common form. The common barberry should be eradicated.

\section{BARBERRY LAWS.}

Attempts to eradicate the common barberry have been made for 200 years or more. The movement is therefore not a mushroom growth, but, on the other hand, it is a gradual and healthy development of a sane idea based on years of careful observation and scientific demonstration.

There is some evidence that a barberry eradication law was passed in Rouen, France, as early as 1660 . Connecticut, Rhode Island, and Massachusetts all enacted laws against the barberry between 1726 and 1766 . The Connecticut and Rhode Island laws were renewed after a period of years, so the results must have been satisfactory.

Several European countries passed laws against the barberry shortly after 1800. Various States in Germany required the eradication of all barberry bushes within a certain distance from grain fields, while still others required all barberry bushes to be removed within a certain specified time. Denmark, in 1869, passed a law which gave any person the 
right to demand the destruction of shrubs which were known to spread plant diseases. One of the provinces of France took advantage of a law passed in that country in 1888 and carried on an energetic campaign against common barberry bushes.

It is difficult to determine the effect of these old laws, because apparently many of them were not rigidly enforced. However, in certain localities in England, on the island of Aero, and, in various other places, the eradication of the barberry was followed by the disappearance of stem rust. Most of these laws were passed before the exact relationship between the barberry and the rust was known. The scientific proof of the relationship was not made until 1865. The early laws, therefore, are the best possible evidence that farmers realized clearly that barberry bushes increased rust, because at the time that these laws were passed people were not biased by any scientific statements regarding the matter.

Recently the movement for barberry eradication has gained great headway. The reason for this fact is that there have been several terrible epidemics of stem rust. These epidemics stimulated investigation of the exact methods by which the rust lived over winter and started in the spring. The evidence against the barberry became so clear and convincing that strong sentiment developed for the removal of the bushes.

For several years a law has been on the statute books of Ontario, Canada, requiring the destruction of the barberry. Recently Manitoba and Saskatchewan have also outlawed the common barberry. In the United States several States have enacted barberry-eradication laws. The Legislature of North Dakota passed such a law in 1917, while during 1918 Colorado, Nebraska, South Dakota, Minnesota, Iowa, and Michigan took legal measures to secure the complete eradication of the common barberry. At this time (April, 1919) bills are also pending before the Legislatures of Wisconsin and Illinois. The fight against the barberry, therefore, is on in earnest. These laws have not been in force long enough to determine their effect, but it is safe to say that the bushes will be completely removed from the upper Mississippi Valley within a few years and that rust attacks will become less frequent and less severe. 
DENMARK CONTROLS RUST.

Practically all common barberry bushes have been eradicated from Denmark since the eradication law of 1903 was passed. The evidence in that country is conclusive. The eradication of the bushes has been followed by unexpectedly beneficial results. The stem rust has done no serious damage since the bushes were removed, although previously it had caused great losses. According to the Danish authorities, all rust attacks which have occurred during the last few years have been very clearly due to the presence of a few barberry bushes which had escaped notice and had not been removed. The results have been so clear that the owners of bushes have destroyed them rapidly.

It is evident, therefore, that Denmark has solved its rust problem by destroying the barberry. In the United States there have been two severe epidemics, causing enormous losses, and several less destructive ones since 1903.

Danish agriculturists visiting in the United States in the last few years have been entirely unable to understand why barberry bushes were permitted to grow in such large numbers in the grain-producing districts of this country.

\section{DIG UP THE COMMON BARBERRY.}

All common barberry bushes should be dug up immediately, especially in the grain-growing States. The plants should not be merely cut off, but should be dug up, root and branch (Pl. X, fig. 2). All the roots should be removed carefully, because new sprouts ( $\mathrm{Pl}$. X, fig. 1) are likely to grow from them. The place from which the bushes were removed should be watched for several years and any sprouts which appear should be dug up and burned. The Japanese species is harmless, but every common barberry bush in the United States should be destroyed. Thousands of bushes have already been destroyed, but thousands remain as a standing menace to our grain crops. Every bush destroyed gives additional insurance to wheat, oats, barley, and rye. Destroy the barberry and protect the grain. 



